Marketing in Asia Group

Asian Journal of Business Research

Volume 9 Issue 2, 2019

ISSN 2463-4522 e-ISSN 1778-8933

DOI: $10.14707 / a j b r .190059$

\title{
Sustaining the Innovation Culture in SMEs: The Importance of Organisational Culture, Organisational Learning and Market Orientation
}

\author{
Hasliza Abdul Halim \\ School of Management, Universiti Sains Malaysia, Penang, Malaysia \\ Noor Hazlina Ahmad \\ School of Management, Universiti Sains Malaysia, Penang, Malaysia \\ T. Ramayah \\ School of Management, Universiti Sains Malaysia, Penang, Malaysia \\ Department of Management, Sunway University Business School, Selangor, Malaysia
}

\begin{abstract}
Previous research on innovation culture among SMEs has received little attention particularly in developing countries. Thus, this paper aims to investigate the influence of organisational culture, organisational learning and market orientation on innovation culture. A total of 183 usable responses were received from SMEs in Malaysia. Findings from the analysis suggest that all dimensions of organisational culture influence innovation culture while organisational learning in terms of information acquisition, behavioural and cognitive also influences innovation culture. Finally, in terms of market orientation, only competitor orientation influences innovation culture. This study contributes to SMEs by providing information on the elements that could nurture innovation culture in their organisations.
\end{abstract}

Keywords: Innovation Culture, Organisational Culture, Organisation Learning, Market Orientation 


\section{Introduction}

The Eleventh Malaysia Plan (2016-2020) introduced by the Malaysian Government is a vital move to transform the country into a developed economy that is inclusive and sustainable (11th Malaysia Plan, 2015). Despite Malaysia's challenges for the past five years due to global economic slowdown, the government believed that with the Government Transformation Programme and the Economic Transformation Programme, as supported by the Tenth Malaysia Plan, the Malaysian Gross Domestic Product (GDP) will continue to grow enormously in the region. During the Tenth Malaysia Plan 2011-2015, the economy of Malaysia had steadily improved in spite of world's mixed performance. Real GDP is expected to improve by 5.3\% per annum; and the nominal per capita Gross National Income (GNI) is anticipated to improve by $5.8 \%$ per annum, i.e. from RM27,819(USD8,636) to RM36,937 (USD10,196) from 2010 to 2015, respectively (11th Malaysia Plan, 2015). Despite of greater precariousness and uncertainty of world's economy due to weakening of oil prices, rationalization of exchange rate, and geopolitical risks, Malaysian economy is anticipated to expand at $5 \%$ to $6 \%$ per annum as a result of sustained domestic demand and external sector's increased contribution.

Moving forward, productivity and innovation will remain as the main supports of Malaysia Eleventh Plan. Despite the past Tenth Malaysia Plan where innovation has been insinuated to, the anticipated results are yet to be fully achieved. The Eleventh Plan will specify strategies and programmes to transform innovation to wealth particularly among the SMEs. Despite facing the uncertainties of global economy, economies that are fairly small yet open such as Malaysia will remain strong. Thus, the government has put many initiatives to strengthen SMEs as the backbone to the economic development and growth. SMEs are given special focus as private sectors and the SMEs are expected to continue their significant role in helping Malaysia to become a developed and inclusive nation (Ndiaye et al., 2018). It has been estimated by recent report that in 2015, Malaysian SMEs contributed $98 \%$ of businesses and $59 \%$ of employment to the nation's economy. Given that more than $99 \%$ of businesses in Malaysia are SMEs, it is crucial to retain a proper economic growth, in the means of employing a large portion of Malaysia's labour force of 12 million people. According to the Prime Minister, Datuk Seri Najib Abdul Razak, the SMEs' growth is to be based on the SME Masterplan (2012-2020) which aims to improve their GDP contribution to $41 \%$ by year 2020 (EPU, 2015).

In line with this scenario, the Malaysian government foresees that SME will continue to be a vital sector which acts as a catalyst in spurring investments and transforming Malaysia into a developed economy by 2020. In fact, Malaysian SMEs is seen as a major contributor to the country's economic growth, which is driven mainly by the service sector at $87 \%$, manufacturing at $7 \%$ and agriculture at $6 \%$. Microenterprises represent majority (79\%) of SMEs (SMEs Master Plan 2010-2020). Despite the Currently SMEs are not achieving superior performance and this is evidenced by the SMEs' contribution to GDP at only 32\%. In fact, Malaysian SMEs' contribution to the nation's GDP is comparatively small when compared with other countries, as depicted in Figure 1 (Asian Development Bank, 2013). 


\section{SMEs in Asia are underserved}

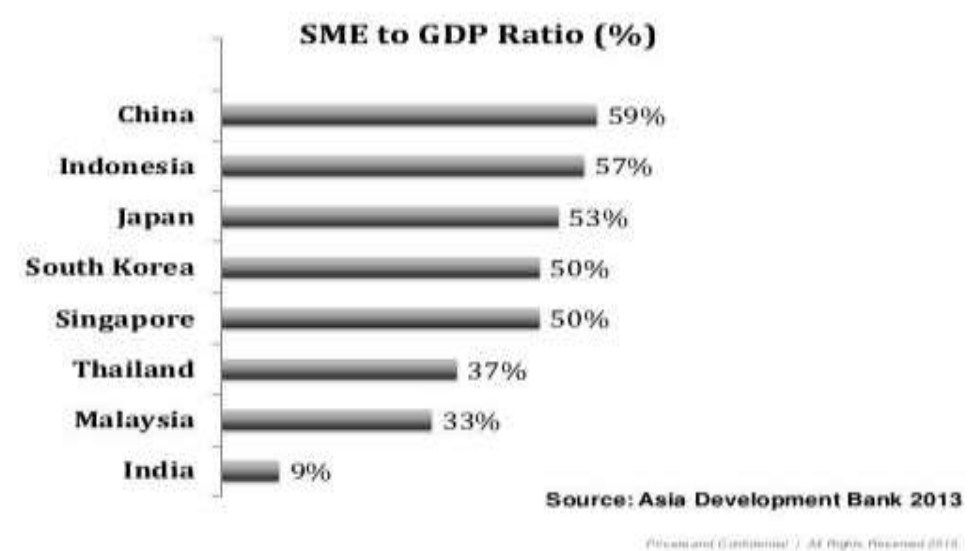

Figure 1: SME Contribution to GDP, \%

Source: Asia Development Bank

Figure 1 shows China's SMEs as the highest contributor to GDP at $60 \%$, Indonesia at $57 \%$ and Japan at 53\%. South Korea and Singapore contributed 50\% each to the GDP and followed by Thailand at 37\%. Sadly however, Malaysia is ranked second last with $33 \%$ of GDP contribution. Although SMEs constitute a large segment of Malaysia's economy with almost 99\% of total established businesses (EPU, 2015), the contribution of the SMEs is small as shown by Figure 1. In this situation SMEs need to intensify their business performance and competitiveness by enhancing their innovative capabilities. However, various studies reported that the adoption of innovation as a culture in SMEs is still at an early phase (REF) (Haslinda Musa, Muruga Chinniah, 2016; Hashim 2007; Denison et al., 2000).

Apparently, the way for SMEs to be innovative is by depending on the entrepreneurs' abilities and creativities to innovate. As Malaysia is on the verge of transforming its economy into an innovation-driven economy, enhancing innovation capabilities especially among SMEs that constitutes a major sector among all business establishments is seen pivotal. Innovation reflects the practice of merging of knowledge, technology, entrepreneurship and innovation to hasten productivity, the centre of economic development (Schumpeter, 1943). Concomitantly, Malaysia has to encourage its manpower to be innovative, creative and proactive as a way of moving towards an innovation-centred economy. Malaysia has to improve on its capabilities of innovating, adapting and creating indigenous technology, designing as well developing and marketing new products (MOSTI, 2010). In view that innovation culture is deemed as the seed that needs planting; the Malaysian government has to promote innovation culture among the SMEs. Indeed, the efforts of improving the competitiveness and success of organizations have a remarkable effect on a nation's economy. In accordance to the vision of Malaysian government to transform the nation's economy by adopting innovative performance via innovation culture among SMEs, this study warrants significant attention. Although, there are many articles published on innovation, of interest, very few studies have deliberated on factors that encourage innovation culture that are crucial to the development in innovative performance (Sharifirad \& Ataei, 2011). 
Accordingly, there are both empirical and theoretical studies that examine the linear or causal relationship of organisational culture, market-orientation, learning orientation, and henceforth, their joint effect on innovation (Mamun et al., 2019; Abdullah et al., 2014; Halim et al., 2015). Nevertheless, most of the empirical studies centred their attention on large organizations of western/developed nations and ignore the SMEs in general, and specifically those of developing nations (Keskin, 2015; Raju et al., 2011). This is because, culture, market orientation and learning are generally less formal, less organized and less sequential in SMEs (Peterson, 1988, Anderson \& Boocock, 2002). In fact, empirical studies on market-orientation, learning-orientation, and innovativeness in SMEs are imperfect or lacked. Consequently, there is surprisingly little information on SMEs' interrelationships among their organisational culture, market-orientation, learning orientation and innovation culture. As such, systematic investigations on the relationship of organisational culture, marketorientation and learning-orientation, and their combined impact on innovation culture as well as the innovation performance are vital to SMEs and scholars. To address this deficiency, the present study presumes that innovation culture could be achieved by leveraging the organisational culture, organisational learning and market orientation.

This study begins with a literature review on innovation culture, the hypotheses development on organisational culture, market orientation and learning orientation on innovation culture in SMEs. This is followed by an outline of the methodology. The findings section reports on findings in relation to the hypotheses. The study's findings are discussed in relation to previous literature. Lastly, conclusion and recommendation are presented.

\section{Literature Review}

\section{Innovation as a Culture among SMEs}

The growth of innovative performance among SMEs has been widely recognised to Malaysia's economic development (Abdul-Halim et al, 2015; Ngah \& Ibrahim, 2012) and as mentioned above, Malaysian government has provided various initiatives to encourage innovation among the SMEs. Even though SMEs' innovation activities have received much attention from researchers (Keskin, 2015; Anahita et al. 2012; Massa \& Testa, 2008), there is a consensus that there are more to be studied (Oke et al., 2007; Lee \& Ging, 2007). Innovation is seen as deviating from the principles, processes and practices of traditional management, or a deviation from usual organisational forms that change the manner a work is done (Hamel, 1994). In contrast, Herkema (2003) posits innovation as embracing new idea or behaviour by the organization; which may be of new product, service or technology. As such, innovation can be significant or gradual whereby it can be the execution of discoveries and process in which new output i.e. product, system, service or process, is realized (Gloet \& Terziovski, 2004; Minh \&Hjorts $\varnothing$, 2015). In similar vein, innovativeness is a process of transforming opportunity into practical use (Keskin, 2015) and occurs only when it is practiced (Sharifirad \& Ataei, 2012). Organisation that has the capability to innovate will obtain better feedback from the environment, easier access to capabilities needed to improve organizational performance and competitive advantage. For this reason, it is vital for an organization to enhance its 
innovation culture as this will cause its workforce to become alert, creative and innovative (Skerlavaj et al., 2010).

Generating value through innovation is undoubtedly a winning strategy. Nevertheless, some organisations will be much better prepared than others to seize the opportunities offered. In this vein, SMEs will be at a considerable disadvantage relative to their larger counterparts. The latter will perpetually have more financial clout, acquire a wider range of skills, greater access to necessary assets pertaining to production and distribution and be better equipped to safeguard intellectual property (Minh \& Hjortsø, 2015). However, big is not always better and it does not indicate that SMEs to be all doom because innovation often relates to part of a product rather than the whole (Zhu et al., 2012). Evidently, SMEs may be able to specialize in specific areas to create new ideas and solutions. For instance, SMEs can get the upper hand in certain conditions like; flexible enough to exploit new technological opportunities; collaborate with strong partnerships which enhance the knowledge and finances needed to obtain key technological competencies; overcome technological limitations by innovating through the use of formal non-R\&D inputs and operating within less technologically intense environments as well as to be intuitive and early to recognise changes in consumer preferences and market trends in order to identify new opportunities (Keskin, 2015).

Nevertheless, for SMEs to achieve innovation they need to have shared beliefs and understanding (Minh \& Hjorts $\varnothing$, 2015); whereby the activities of innovation occur within the stipulated social and economic contexts, as well as the cultural and political tradition of the country (Wan Ismail \& Abdul Majid, 2007). Various studies have examined the relationship between innovation orientation, and size, age and organizational structure (Laforet \& Tann, 2006); firm-professional relationship (Zhu et al., 2012); innovation capabilities, relationship with knowledge centres, and R\&D expenditure (Keizer et al., 2002); and, customer and market orientation (Keskin, 2015; Appiah-Adu \& Singh, 1998). Given the intricacies and difficulties of innovation, it is realized that cultural perspective may be accepted in understanding innovation (Jaskyte, 2004; Brettel, Chomik, \& Flatten, 2015). Subramaniam (1996) posits that organisational features of innovative organisations differ from noninnovative organisations. As such, an innovative organization, including an SME needs to embrace 'a culture of pride and climate of success' (Anahita, et al., 2012; Kanter, 1983). In line with this, Tushman \& O'Reilly (1997) also posit culture as a part of vital elements in innovation management. This is because to succeed in every business environment, the understanding of values that drive and promote the culture of the environment is important. For this study's purpose, innovation culture is deemed to be of multi-dimensional; and consists of the desire to be innovative, infrastructure that supports innovation, operational behaviour to affect the market as well as value orientation and environment to embrace innovation (Dobni, 2008). Considering this, in order to cultivate and maintain innovation culture, SMEs have to adopt a participative management culture in which communication and network are optimised, and flexible structure, empowering employees, risk taking, orientation, learning and knowledge are welcomed. In is envisioned that the correct mix of these factors will cause innovation to flourish. 


\section{Hypotheses Development and Research Framework}

\section{Organisational Culture and Innovation Culture}

Creativity, novelty and innovation are highly vital in supporting innovation and this is normally motivated by organizational culture (Sharifirad \& Atei, 2012). Organizational culture is a significant instrument (Sackmann, 1991). Moreover, organizational culture acts as a control mechanism to establish organizational commitment as well as assist the organization in adapting to the external changes. As such, SMEs are assumed to have strong organizational structure due to their size and the presence of owner-managers (Wilson \& Bates, 2003; Denison \& Mishra, 1995; Denison \& Neale, 1996).

At the same time, organisational culture is also implied as the core for innovative activities implemented by the organisation. How does an innovative organization look like? It is where its entrepreneur is enthusiastic and highly convinced to keep on experimenting new ideas (Brettel, Chomik, \& Flatten, 2015). Here, the entrepreneur possesses the right knowledge, skill and ability to successfully formulate and implement new ideas. Nonetheless, innovation will only prosper if the work environment supports the endeavours (Kaasa \& Vadi, 2008). This means that for SMEs to come out with creative product and service, they have to be given the chance to search, examine and experiment (Fauzi et al., 2010). In a wider sense, innovation is important for survival of businesses, government agencies and institutions (Wan Khairuzzaman \& Abdmajid, 2007). Thus, to successfully competing and sustaining locally and globally, the organizations must have the structure and process as to allow the development of innovation. Innovation management revolves around generating a culture where new ideas are formulated, valued and supported (Sarooghi, 2015; Streets \& Boundary, 2004). To achieve 'innovation performance' is not easy as it requires suitable road map or strategies and they are practiced (Raduan et al., 2009). Here, organizational culture might influence innovation, rendering it prevalent or uncommon in parts of organizations. (Sharifirad \& Ataei, 2012; Brettel, Chomik, \& Flatten, 2015). In fact, organizational culture has to be properly nurtured as it may encourage or stop creativity and innovation (Gandotra, 2010). This study's model of organizational culture is based on four cultural traits which are involvement, consistency, adaptability, and mission; and these traits have been found by the literature to affect performance (Denison, 1990; Denison \& Mishra, 1995; Sorenson, 2002). These arguments lead to the following hypotheses:

H1 Adaptability is positively related to innovation culture.

H2 Involvement is positively related to innovation culture.

H3 Mission is positively related to innovation culture.

H4 Consistency is positively related to innovation culture. 


\section{Organisational Learning and Innovation Culture}

Many past studies have noted on the positive relationship between organizational learning and organization innovation (e.g., Calantone et al., 2002; Jiménez-Jiménez \& Sanz-Valle, 2011). This is because organizational learning generates knowledge and ideas (e.g., Lopez et al., 2004; Damanpour, 1991; Dishman \& Pearson, 2003), supports originality and improves the ability of understanding and applying them (Aragón-Correa et al., 2007). Huber (1991) and Lopez et al. (2004) view organizational learning as a mix of four processes, namely information acquisition, information distribution, information interpretation and organisational memory. The creation, acquirement and transfer of knowledge are strong in organizations with good learning culture, as well as changing the behaviour to echo the recent knowledge and insight (Garvin, 1993). Therefore, organisations focusing on organisational learning must first acquire information, interpret it to fully understand its meaning and transform it into knowledge. Additionally, the important part is to implement behaviour and cognitive changes - converting words into action must also put into place. Even though the literature agrees on the relationship between organizational learning and innovation, there are very limited studies that adopt a cultural approach for measuring the organizational learning particularly among SMEs (Keskin, 2006; Lee \& Tsai, 2005; Mavondo et al., 2005; Ussahawanitchakit, 2008). Past research had focused on the orientation of innovation, i.e. the degree of firm culture in promoting and supporting innovation (Hult et al., 2004; Hurley \& Hult, 1998; Keskin, 2006; Lee \& Tsai, 2005; Ussahawanitchakit, 2008) and heading towards an innovation culture holistic model, a vital element of organisation learning (Skerlavaj et al., 2010). Based on the above arguments, it is proposed that:

H5 Information acquisition is positively related to innovation culture.

H6 Information interpretation is positively related to innovation culture.

H7 Behavioural and cognitive learning is positively related to innovation culture.

\section{Marketing Orientation and Innovation Culture}

Another interesting element is the market orientation. Market orientation is the culture of organisations that supports the behaviour that determines how an employee should think and act in view that it is related to the execution of marketing concept (Day, 1990; Narver \& Slater, 1990). The elements under market orientation encompass market sensing, customer linking, competitor sensing and customer service. Other elements, namely technological development, new product/service development and organisational communication are also deemed as the key capabilities. To date, the endeavour to discover the constructs of market orientation in the cultural antecedent context has been significant (Kohli \& Jaworski, 1990; Dobni, 2008). This is being driven by the fact the areas of market orientation and innovation are connected, and policies examined in innovation scale are significantly adopted by market-oriented organizations (O’Cass \&Ngo, 2007; Pérez-Luño, Saparito, \& Gopalakrishnan, 2016).

In general, market orientation is related to organizational culture that stresses on the orientations of customer and competitor, interfunctional coordination as well as responsiveness, which are vital to the success of an organization (Kohli \& Jaworski, 
1990; Narver \& Slater, 1990; Pérez-Luño et al., 2016). Although previous studies focused on the on the link between market orientation and performance, the endeavour to comprehend the effects of culture on innovation among smaller organizations is inadequate (Keskin, 2015; Nasution et al., 2011; Dobni, 2008). Past research posited that the role of market orientation in SMEs is slightly different compared to larger organizations and it is very interesting to examine the effect of market orientation on innovation culture. Therefore, it is proposed that:

H8 Consumer orientation is positively related to innovation culture.

H9 Competitor orientation is positively related to innovation culture.

\section{Application of Conceptual Model to SMEs}

In Malaysia, being innovative is imperative not only among large organisations but importantly SMEs given their large compositions. This is because economic progress is dependent upon industrial growth, which also influences social development (Zeng, Xie \& Tam, 2010); and businesses are no longer focusing on reduction of cost; instead innovation is geared toward long term growth (Shah Alam \& Mohd Yasin, 2010). A majority of studies focused on the elements of intra-organization which examine the structure, culture, strategies and managerial concept of organizations in determining innovative performance. They posit that the elements of intraorganisational as the organisations' resources and capabilities in facilitating the organisations' external environment surveillance and to adapt to changes and effects of innovation. This also means that the development of new products and process do account organizational culture that is extensive and intensive. Organizational culture is relied upon by organization that succeeded in innovation, which are the employees' actions and behaviour (Madhousi et al., 2011). In enhancing performance through processes and system, organisations can adopt innovation which ranges from desire to innovate, to the capacity to generate new product, service or ideas. Another vital point of innovativeness is openness to innovation, as proven by the relationship between organisational culture, learning and market orientation and innovation. The culture of innovating is about the attention required in recognizing the need for innovative performance. As such, it is highlighted that innovation culture has a vital role in organisations' innovative performance. Figure 2 exhibits research framework for this study.

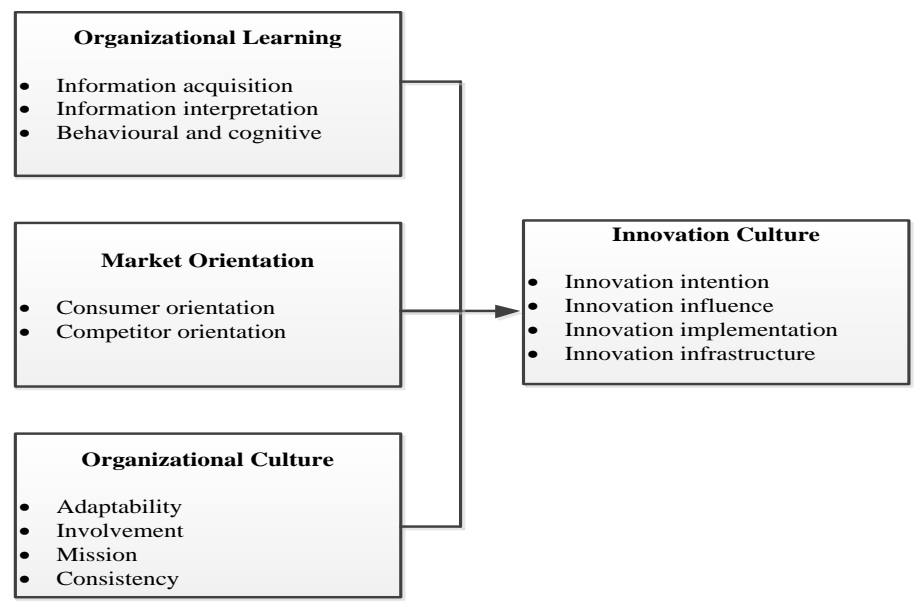

Figure 2: Research Framework 


\section{Methodology}

\section{Sample and Procedures}

This empirical study which is quantitative employs purposive sampling in the gathering of data from Malaysian SMEs through self-administered questionnaire. The analysis unit of study is the SMEs' owners. In view that this study concentrates on SME entrepreneurs, the definition of SME is adopted from the Small and Medium Industries Development Corporation (SME Corps, 2013) in identifying the appropriate businesses for the study. The SME Corps' directory will be utilized to identify the sample that has the following characteristics: (1) belongs to innovative sector; (2) less than 150 employees for manufacturing, and less than 50 employees for service sector; and (3) a stand-alone company, not part of franchise or larger companies. Those franchised SMEs or part of larger companies are excluded as most of them do not have the control over their operations. Shefsky $(1994$, p.82) stated that for the franchisees, "there does not seem much room to do your own thing" as they are supervised by parent company and have to follow the stipulated rules and regulations.

In this study, 183 data were usable for analysis out of 196 respondents. The respondents' company has been established since year 1976 till 2014. Most respondent were from the service sectors $(56.3 \%)$ and the remaining respondents were from manufacturing and agriculture. Among the surveyed SMEs, 50.8 percent of the SMEs were operating their businesses in Malaysia and the rest was either in local or foreign market. In terms of educational level, around 27.9 per cent of the respondents' held a bachelor's degree, 24 percent of them only went to high school, 20.8 per cent obtained certificate, and 18.6 percent received diploma and almost 5 per cent of the business owners had master and above degree. Finally, only 4.4 percent of them had less than high school education.

\section{Measurement Instruments}

Multi-item scales were used to measure organisational cultures, organisational learning, market orientation and innovative culture. A 5-point Likert scales ( $1=$ strongly disagree to $5=$ strongly agree) were used to measure the level of respondents' agreeableness on the statement posed to them. A questionnaire was developed from past studies and modified to suit the context of the study.

\section{Organisational Culture}

In order to develop the scale for organisational culture, these items have been developed from Denison et al (2006). This approach concentrates on the aspects of organizational culture that seem to affect the effectiveness of an organisation. It focuses on four traits and those are involvement, consistency, adaptability and mission. The focus of these traits is also supported by other studies of organizational culture and effectiveness (Kotter \& Heskett, 1992; Denison \& Mishra, 1995; Denison $\&$ Neale, 1996). 


\section{Organisational Learning}

To measure the dimensions of organisational learning, the scales were adapted from Lopez et al. (2004) which were based on four dimensions; namely information acquisition, information interpretation and behavioural \& cognitive.

\section{Market Orientation}

Narver and Slater (1990, p.21) had determined market orientation as "the organization- culture that most effectively and efficiently creates the necessary behaviours for the creation of superior value for buyers and, thus continuous superior performance for the business". For this study's purpose, the items for market orientation scale were based on two dimensions; namely consumer orientation and competitor orientation which were adapted from Narver and Slater (1990) and Nasution et al. (2011).

\section{Innovation Culture}

The development of the innovation culture scales was rooted in strategic management and innovation literature. The innovation culture scale developed in this study was adapted from Dobni (2008). Four dimensions were used for this study namely intention, infrastructure, influence and implementation.

\section{Data Analysis}

According to Podsakoff et al. (2003), if the data were collected from single source, common method variance needs to be examined. A usual method of identifying this problem is by utilizing the Harman's single factor test; that is by the admission of all main constructs into principal component factor analysis (Podsakoff \& Organ, 1986). The findings show that 9 factor explains 63. 36\% and the first factor explained 36.94 $\%$, which is lower than the $50 \%$. It indicates that common method bias is not an issue in this study.

To analyse the study model, we applied the Partial Least Squares technique by the SmartPLS 3.0 software (Ringle et al., 2015). Measurement model (validity and reliability) and structural model (testing the relationship among variables) were tested using this software.

\section{Measurement Model}

In this research, the latent variable of innovation culture had been considered as a second order reflective construct where first order constructs (innovation intention, innovation influence, innovation implementation, and innovation infrastructure) hold reflective measurements that refer to the reflective-reflective type. According to the literature, higher order is included as to decrease the number of relationships (and simultaneously the number of hypothesis to be tested) in the structural model; and so that the PLS path model be more parsimonious and easier to understand (Hair et al., 2013; MacKenzie et al., 2005). Following Becker et al. (2012), repeated indicator approach has been used in this research to model hierarchical latent variables. In the first stage of the repeated indicator approach, the latent variable scores obtained for 
the first order constructs which in the second stage served as manifest variables in the hierarchical order construct.

The convergent validity and discriminant validity were used to examine the measurement model. As suggested by Hair et al. (2014), factor loading, average variance extract (AVE) and composite reliability are to be considered in determining convergent validity. The results showed that all the items loading was higher than 0.5 , the AVE were higher than 0.5 , and also the CR were above 0.7 (Table 1).

In assessing discriminant validity (i.e. the extent the items distinguish constructs or examine different concepts), the Fornell and Larcker (1981) criterion has been utilized in comparing the correlations between constructs and the square root of the average variance extracted for that construct. Table 2 shows the results of discriminant validity in the study. The measures were found to be discriminant in view that all values in diagonals were more than the corresponding row and column.

Table 1: Measurement Model

\begin{tabular}{|c|c|c|c|c|c|}
\hline $\begin{array}{l}\text { First Order } \\
\text { Construct }\end{array}$ & $\begin{array}{l}\text { Second Order } \\
\text { Construct }\end{array}$ & Item & Loading & $\overline{\text { AVE }}$ & $\mathbf{C R}$ \\
\hline \multirow{3}{*}{$\begin{array}{l}\text { Information } \\
\text { acquisition }\end{array}$} & & IA1 & 0.749 & 0.563 & 0.794 \\
\hline & & IA2 & 0.679 & & \\
\hline & & IA3 & 0.816 & & \\
\hline \multirow{3}{*}{$\begin{array}{l}\text { Information } \\
\text { interpretation }\end{array}$} & & II1 & 0.865 & 0.645 & 0.845 \\
\hline & & II2 & 0.755 & & \\
\hline & & II3 & 0.787 & & \\
\hline \multirow{3}{*}{$\begin{array}{l}\text { Behavioural and } \\
\text { cognitive }\end{array}$} & & $\mathrm{BC} 1$ & 0.737 & 0.551 & 0.786 \\
\hline & & $\mathrm{BC} 2$ & 0.785 & & \\
\hline & & $\mathrm{BC} 3$ & 0.702 & & \\
\hline \multirow[t]{3}{*}{ Consumer orientation } & & ComO1 & 0.800 & 0.701 & 0.875 \\
\hline & & ComO2 & 0.863 & & \\
\hline & & ComO3 & 0.847 & & \\
\hline \multirow[t]{3}{*}{ Competitor orientation } & & ConO1 & 0.853 & 0.750 & 0.900 \\
\hline & & $\mathrm{ConO} 2$ & 0.883 & & \\
\hline & & $\mathrm{ConO} 3$ & 0.863 & & \\
\hline \multirow[t]{3}{*}{ Adaptability } & & Adap1 & 0.568 & 0.603 & 0.816 \\
\hline & & Adap2 & 0.869 & & \\
\hline & & Adap3 & 0.856 & & \\
\hline \multirow[t]{5}{*}{ Involvement } & & Involv1 & 0.785 & 0.645 & 0.879 \\
\hline & & Involv2 & 0.820 & & \\
\hline & & Involv3 & 0.809 & & \\
\hline & & Involv4 & 0.798 & & \\
\hline & & Mission1 & 0.841 & 0.73 & 0.915 \\
\hline \multirow[t]{3}{*}{ Mission } & & Mission2 & 0.873 & & \\
\hline & & Mission3 & 0.866 & & \\
\hline & & Mission4 & 0.838 & & \\
\hline \multirow[t]{3}{*}{ Consistency } & & Cosis 1 & 0.788 & 0.628 & 0.871 \\
\hline & & Cosis2 & 0.813 & & \\
\hline & & Cosis3 & 0.785 & & \\
\hline
\end{tabular}




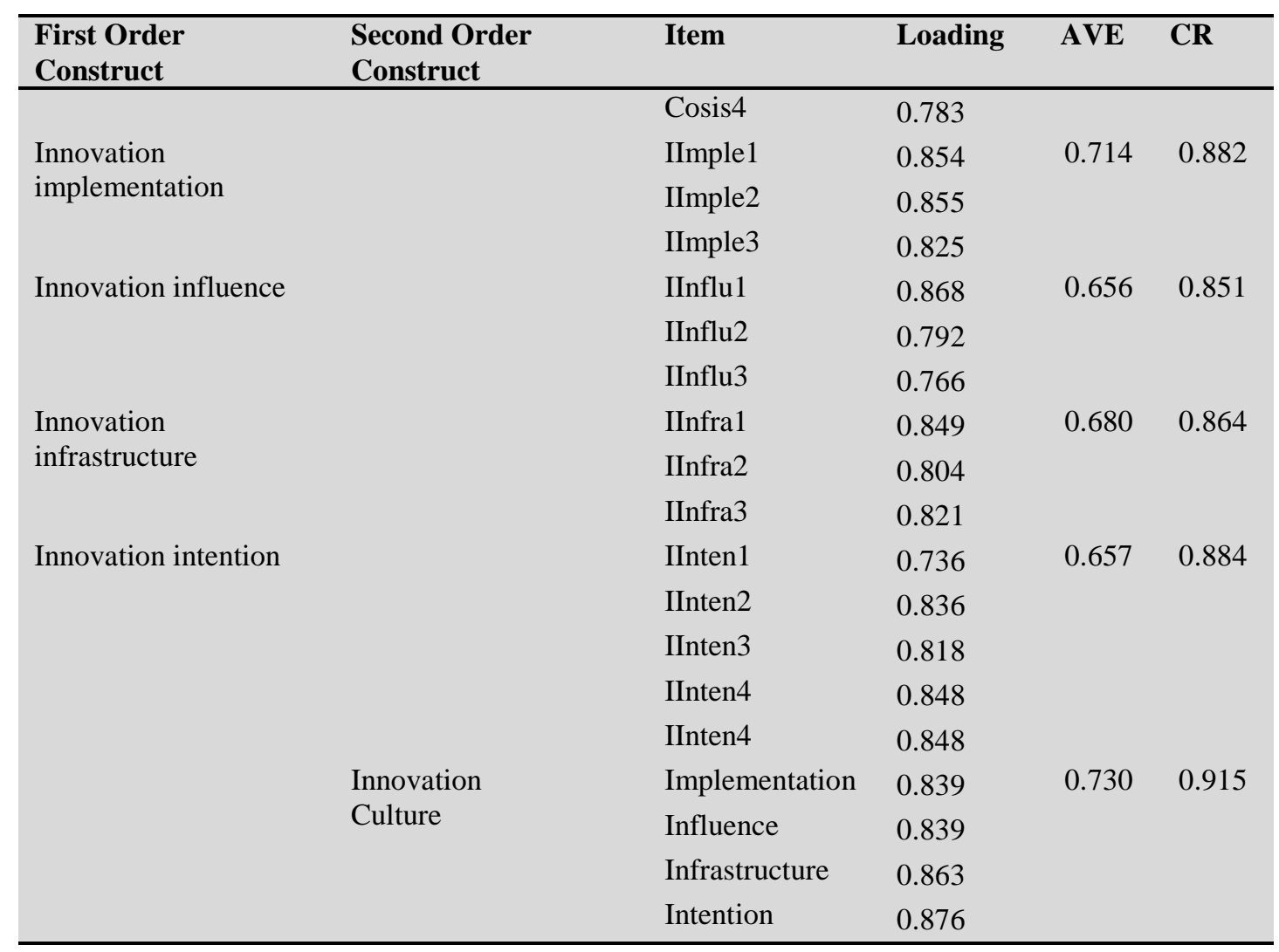

Table 2: Discriminant Validity

\begin{tabular}{llllllllllll}
\hline & & $\mathbf{1}$ & $\mathbf{2}$ & $\mathbf{3}$ & $\mathbf{4}$ & $\mathbf{5}$ & $\mathbf{6}$ & $\mathbf{7}$ & $\mathbf{8}$ & $\mathbf{9}$ & $\mathbf{1 0}$ \\
\hline $\mathbf{1}$ & Adaptability & $\mathbf{0 . 7 7 7}$ & & & & & & & & \\
$\mathbf{2}$ & $\begin{array}{l}\text { Behavioural and } \\
\text { cognitive }\end{array}$ & 0.216 & $\mathbf{0 . 7 4 2}$ & & & & & & & \\
& $\begin{array}{l}\text { Competitor } \\
\text { orientation }\end{array}$ & 0.527 & 0.286 & $\mathbf{0 . 8 3 7}$ & & & & & & & \\
$\mathbf{4}$ & $\begin{array}{l}\text { Consumer } \\
\text { orientation }\end{array}$ & 0.465 & 0.381 & 0.533 & $\mathbf{0 . 8 6 6}$ & & & & & & \\
$\mathbf{5}$ & $\begin{array}{l}\text { Consistency } \\
\mathbf{6}\end{array}$ & 0.583 & 0.427 & 0.505 & 0.611 & $\mathbf{0 . 7 9 2}$ & & & & & \\
& acquisition & 0.386 & 0.454 & 0.394 & 0.453 & 0.481 & $\mathbf{0 . 7 5 0}$ & & & & \\
$\mathbf{7}$ & $\begin{array}{l}\text { Information } \\
\text { interpretation }\end{array}$ & 0.444 & 0.192 & 0.268 & 0.520 & 0.514 & 0.437 & $\mathbf{0 . 8 0 3}$ & & & \\
$\mathbf{8}$ & Innovation culture & 0.650 & 0.500 & 0.626 & 0.587 & 0.719 & 0.543 & 0.405 & $\mathbf{0 . 7 0 2}$ & & \\
$\mathbf{9}$ & Involvement & 0.596 & 0.269 & 0.378 & 0.543 & 0.686 & 0.337 & 0.571 & 0.624 & $\mathbf{0 . 8 0 3}$ & \\
$\mathbf{1 0}$ & Mission & 0.574 & 0.376 & 0.509 & 0.598 & 0.681 & 0.490 & 0.474 & 0.762 & 0.605 & $\mathbf{0 . 8 5 4}$ \\
\hline
\end{tabular}

Note: Values on the diagonal (bolded) are square root of the AVE while the off-diagonals are correlations 


\section{Structural Model}

To assess the structural model (Figure 3), R2, beta, t-values via a bootstrapping procedure with a resample of 1000 , the predictive relevance (Q2), and the effect sizes (f2) as suggested by Hair et al. (2014) was performed.

The results (Table 3) indicated that out of nine predictors of innovation culture, seven predictors had significant relationship with innovation culture. Adaptability (H1) $\beta=$ $0.170(\mathrm{p}<0.01)$, involvement (H2) $\beta=0.136(\mathrm{p}<0.01)$, mission (H3) $\beta=0.328(\mathrm{p}<$ 0.01 ), and consistency (H4) $\beta=0.145$ ( $\mathrm{p}<0.01$ ) had positive relationship with innovation culture. Thus, for $\mathrm{H} 1, \mathrm{H} 2, \mathrm{H} 3$ and $\mathrm{H} 4$ were supported. For organisational learning only information acquisition (H5) $\beta=0.099(\mathrm{p}<0.05)$ and behavioural \& cognitive learning $(\mathrm{H} 7) \beta=0.164(\mathrm{p}<0.01)$ were supported while information interpretation (H6) was not supported. Finally, for market orientation competitor orientation (H9) $\beta=0.190$ ( $p<0.01$ ) was supported while consumer orientation (H8) was not supported. The R2 value for innovation culture is 0.759 which is above the 0.26 value as suggested by Cohen (1988) indicating a substantial model. Hair et al. (2014) have suggested that to examine the change in the R2 value to see the f2. The method suggested is to omit a specific exogenous construct from the model and see the R2 change. It can be used to evaluate whether the omitted construct has a substantive impact on the endogenous constructs. Table 3 shows the results of $\mathrm{f} 2$. Following the Cohen (1988) guideline, the effect size of 0.02, 0.15, and 0.35, respectively, represent small, medium, and large effects.

In addition, Table 3 exhibits the predictive relevance of the model through the blindfolding procedure. If the $\mathrm{Q} 2$ value is larger than 0 , the model has predictive relevance for a certain endogenous construct (Hair et al., 2014). Based on the results, the $\mathrm{Q} 2$ values for innovation culture $(\mathrm{Q} 2=0.363)$ is more than 0 suggesting that the model has sufficient predictive relevance. Hair et al. (2014) stated that values of 0.02, 0.15 , and 0.35 indicate that an exogenous construct has a small, medium, or large predictive relevance for a certain endogenous construct.

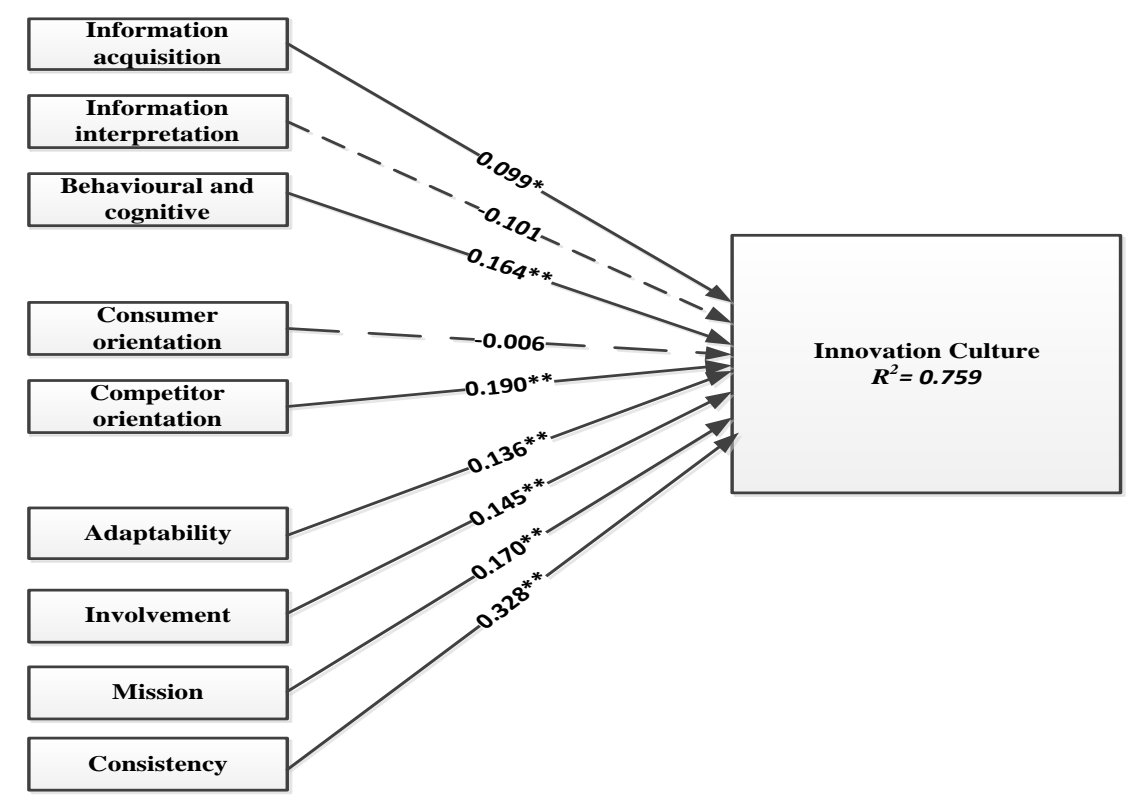

Note: $* * \mathrm{p}<0.01, * \mathrm{p}<0.05$

Figure 3: Structural Model 
Table 3: Structural Modal

\begin{tabular}{|c|c|c|c|c|c|c|c|c|}
\hline & & Beta & SE & t-value & Decision & $\mathbf{R}^{2}$ & $\mathbf{f}^{2}$ & $\mathbf{Q}^{2}$ \\
\hline H1 & $\begin{array}{l}\text { Information acquisition -> } \\
\text { Innovation Culture }\end{array}$ & 0.099 & 0.048 & $2.093^{*}$ & Supported & 0.759 & 0.024 & 0.363 \\
\hline H2 & $\begin{array}{l}\text { Information interpretation -> } \\
\text { Innovation Culture }\end{array}$ & -0.101 & 0.064 & 1.578 & $\begin{array}{l}\text { Not } \\
\text { Supported }\end{array}$ & & 0.013 & \\
\hline H3 & $\begin{array}{l}\text { Behavioural and cognitive -> } \\
\text { Innovation Culture }\end{array}$ & 0.164 & 0.048 & $3.425 * *$ & Supported & & 0.078 & \\
\hline H4 & $\begin{array}{l}\text { Consumer orientation -> } \\
\text { Innovation Culture }\end{array}$ & -0.006 & 0.054 & 0.114 & $\begin{array}{l}\text { Not } \\
\text { Supported }\end{array}$ & & 0.000 & \\
\hline H5 & $\begin{array}{l}\text { Competitor orientation -> } \\
\text { Innovation Culture }\end{array}$ & 0.190 & 0.059 & $3.231 * *$ & Supported & & 0.085 & \\
\hline H6 & $\begin{array}{l}\text { Adaptability -> Innovation } \\
\text { Culture }\end{array}$ & 0.170 & 0.051 & $3.308^{* *}$ & Supported & & 0.059 & \\
\hline H7 & $\begin{array}{l}\text { Involvement -> Innovation } \\
\text { Culture }\end{array}$ & 0.136 & 0.057 & $2.405 * *$ & Supported & & 0.031 & \\
\hline H8 & $\begin{array}{l}\text { Mission -> Innovation } \\
\text { Culture }\end{array}$ & 0.328 & 0.057 & $5.797 * *$ & Supported & & 0.188 & \\
\hline H9 & $\begin{array}{l}\text { Consistency -> Innovation } \\
\text { Culture }\end{array}$ & 0.145 & 0.056 & $2.584 * *$ & Supported & & 0.031 & \\
\hline
\end{tabular}

Note: $* * \mathrm{p}<0.01,{ }^{*} \mathrm{p}<0.05$

\section{Discussion}

Given the dynamic business landscapes, SMEs need innovation to enhance their performances. This study contributes to the body of knowledge in innovation field by demonstrating that organisation culture, organisational learning and market orientation contribute to the development of innovation culture in the SMEs. Specifically, the findings suggest that all four dimensions of organisational culture namely adaptability, involvement, consistency and mission are important in enhancing innovation culture of the organisations. In contrast, two dimensions have been found to be vital in assisting SMEs to improve on their employees' innovation culture, those are acquisition of information, and behavioural and cognitive. In terms of market orientation, only competitor orientation is significantly related to innovation culture.

The SMEs' innovation culture will allow them to ensure their competitiveness in an unstable market. They can take the advantage of innovation culture as to ensure their businesses are creative, efficient and attain the targeted goals. In order to have an innovation culture, SMEs need to inculcate a culture that supports innovation. Organizational culture influences innovation and may spread to other divisions of the organization (Shahrifirad \& Ataei, 2012). Organizational culture may encourage or halt creativity and innovation if it is not adequately nurtured. Cultural openness to 
innovation is a vital element of innovativeness as proven by the relationship between organizational culture and organizational learning, and innovation. In addition, SMEs also view market orientation specifically competitor orientation plays an important role to foster innovation culture. When market is unstable or competition is intense, as such competitive-oriented is critical to inculcate innovation. Apparently, customer orientation does not affect innovation culture, and this is because the SMEs have not given priority on the required resources in responding to their consumers' demand. Perhaps, when the SMEs are competitive and respond well to dynamism of competition in the marketplace could concurrently provide multiples choices of products and services to consumers. In turn, SMEs will remain as market oriented in order to compete effectively.

Innovation culture promotes the sharing of information. As organizational learning deals with the sharing of knowledge and information, this motivates the generation of ideas for development of new products. To have such platform will help the SMEs to embrace innovation and search for new process methods. This will result in the SMEs benefiting from the innovation culture while competing in a competitive market. Information sharing will result in the degree of idea development to improve. Nonetheless, the collected knowledge has to be easily understood and improved their knowledge. Indeed, behaviour and cognitive play an important role in innovation culture; hence leading to innovative performance.

\section{Managerial Implications}

The major implication of this study for practitioners and academics is that it requires the combination of appropriate internal characteristics to enable SMEs to innovate.. This is because SMEs owners may encounter difficulties in terms defining innovation culture as well as understanding the appropriate methods of producing real innovation. The difficulties are not setbacks of innovation, but they are due to the lack of understanding of the challenging conditions necessary in adopting the culture of innovation. In this respect, the SMEs must be able to understand that internal and great amount of resources may not be necessary to achieve innovation. Organizational culture, capability of organisational learning and market orientation are the appropriate examples of internal conditions needed by SMEs in inculcating innovation culture.

Additionally, this study contributes the innovation literature and SMEs. First, this study has examined the innovation practice's primary determinants. Specifically, this study examined the suggestion that organisational culture has an impact on innovation culture. This study's findings make a contribution the body of knowledge whereby all dimensions of organisational culture were found to influence the innovation culture in SMEs. This study also contributes to theory by showing support on the importance of organisational learning (information acquisition and behavioural \& cognitive) in generating innovation. This result is also appealing in which competitor orientation has been proven to impact innovation culture. Therefore, a common perspective integrating all these three core dimensions is a prerequisite for the SMEs' innovation culture. In fact, this study's findings will provide the SMEs with a fresh perspective that the concept of innovation culture needs to be adopted by them; as to move from traditional business operation to being innovative. 


\section{Conclusions, Limitations, and Future Directions}

This study is not without its limitations. Depending on a single respondent (owner of SMEs) could be viewed as a limitation of the study; however the study has taken necessary step to minimise the bias. The common method bias utilizing Harman's one-factor test was undertaken and it was found that there is no such bias (Podsakoff \& Organ, 1986; Scott \& Bruce, 1994). Secondly, the cross-sectional design has constrained this study. Even though nearly all plausible directions for the framework's pathway had been performed, the longitudinal research is desired in order to observe the relationship's causality direction and identify possible process of reciprocal.

In summary, innovation culture concept is the pillar of innovation. It is where entrepreneurs feel encouraged and assured to constantly attempt new endeavours. Here, the entrepreneur is equipped with the right knowledge, skill and ability to successfully produce and execute new ideas. Nonetheless, innovation only prosper in the long run as business owners need to be fully committed in the nurturing of innovation as their employees might resist change. The management of innovation is related to the creation of culture whereby new ideas are produced, appreciated and backed. To attain the status of 'innovation performance' is a challenging endeavour in the absence of suitable road map or planning, in which they are outlined and practiced.

\section{Acknowledgement}

This study is supported through the Fundamental Research Grant Scheme (FRGS) granted by the Ministry of Education, Malaysia (203/PMGT/6711585).

\section{References}

Anderson, V., \& Boocock, G., (2002), Small firms and internationalisation: Learning to manage and managing to learn, Human Resource Management Journal, vol. 12, pp. $5-24$.

Anahita, B., Jennifer, R, Sally, S., \& Daffyd, D., (2012), Innovation in food sector SMEs, Journal of Small Business and Enterprise Development, vol. 19, no. 2, pp. 300 - 321.

Aragón-Correa, J. A., García-Morales, V. J., \& Cordón-Pozo, E., (2007), Leadership and organizational learning's role on innovation and performance: Lessons from Spain, Industrial Marketing Management, vol. 36, no. 3, pp. 349-359.

Asian Development Bank, (2013), "Asia SME Finance Monitor 2012", Retrieved from http://adb.org/sites/default/files/pub/2014/asia-sme-finance-monitor-2013.pdf

Becker, J. M., Klein, K., \& Wetzels, M., (2012), Hierarchical latent variable models in PLSSEM: Guidelines for using reflective-formative type models, Long Range Planning, vol. 45, no. 5, pp. 359-394.

Brettel, M., Chomik, C., \& Flatten, T. S., (2015), How organizational culture influences innovativeness, proactiveness, and risk-taking: Fostering entrepreneurial orientation in SMEs, Journal of Small Business Management, vol. 53, no. 4, pp. 868-885.

Cohen, J., (1988), Statistical power analysis for the behavioral sciencies, Routledge.

Calantone, R. J., Cavusgil, S. T., \& Yushan, Z., (2002), Learning orientation, firm innovation capability, and firm performance, Industrial Marketing Management, vol. 31, no. 6, pp. 515-524. 
Damanpour, F., (1991), Organizational innovation: A meta-analysis of effect of determinants and moderators, Academy of Management Journal, vol. 34, no. 3, pp. 555-590.

Day, G. S., (1990), Market-driven strategy: Processes for creating value, Free Press.

Department of Statistic Malaysia, (2011), "Census report on SMEs, 2011", Retrieved from http://www.statistics.gov.my

Dobni, C. B., (2008), Measuring innovation culture in organizations: The development of a generalized innovation culture construct using exploratory factor analysis, European Journal of Innovation Management, vol. 11, no. 4, pp. 539 - 559.

Denison, D., (1990), Corporate culture and organizational effectiveness, John Wiley \& Sons.

Denison, D., \& Neale, W., (1996), Denison organizational culture survey, Ann Arbor.

Denison, D. R., Janovics, J., Young, H. J., \& Cho., (2006), Diagnosing organizational cultures: Validating a model and method, Denison Consulting Group.

Denison, D. R., \& Mishra, A. K., (1995), Toward theory of organizational culture and effectiveness, Organizational Science, vol. 6, no. 2, pp. 204-223.

Dishman, P., \& Pearson, T., (2003), Assessing intelligence as learning within an industrial marketing group: A pilot study, Industrial Marketing Management, vol. 32, no. 7, pp. 615-20

Eleventh Malaysian Plan, (2015), "Enhancing inclusiveness towards an equitable society", Retrieved from http://rmk11.epu.gov.my

Fornell, C., \& Larcker, D. F., (1981), Evaluating structural equation models with unobservable variables and measurement error, Journal of Marketing Research, vol. 18 , no. 1 , pp. 39-50.

Gandotra, N. K., (2010), Innovation culture for sustainable competitive advantage, Sri Krishna International Research \& Educational Consortium, vol. 1, no. 2, pp. 22294104.

Garvin, D. A., (1993), Building a learning organization, Harvard Business Review, vol. 71, pp. 78-91.

Gloet, M., \& Terziovski, M., (2004), Exploring the relationship between knowledge management practices and innovation performance, Journal of Manufacturing Technology Management, vol. 15, no. 5, pp. 402-411.

Hair, J. F., Hult, G. T. M., Ringle, C., \& Sarstedt, M., (2013), A primer on partial least squares structural equation modeling (PLS-SEM), SAGE Publications.

Hamel, G., \& Prahalad, C. K., (1994), Strategy as a field of study: Why search for a new paradigm?, Strategic Management Journal, vol. 15, no. 2, pp. 5-16.

Halim, H. A., Ahmad, N. H., Ramayah, T., Hanifah, H., Taghizadeh, S. K., \& Mohamad, M. N., (2015), Towards an innovation culture: Enhancing innovative performance of Malaysian SMEs, Academic Journal of Interdisciplinary Studies, vol. 4, no. 2, pp. 8594.

Hult, G. T. M., Tomas, Hurley, R. F., Knight, G. A., (2004), Innovativeness: Its antecedents and impact on business performance, Industry of Marketing Management, vol. 33, no. 5, pp. 429-438.

Hurley, R. E., \& Hult, G. T. M., (1998), Innovation, market orientation and organizational learning: An integration and empirical examination, Journal of Marketing, vol. 62, pp. $42-54$.

Herkema, S., (2003), A complex adaptive perspective on learning within innovation projects, The Learning Organization, vol. 10, no. 6, pp. pp. 340-346.

Huber, G., (1991), Organizational learning: The contributing processes and the literatures, Organizations Science, vol. 2, no. 1, pp. 88-115.

Jaskyte, K., (2004), Transformational leadership, organizational culture and innovativeness in nonprofit organizations, Nonprofit Management and Leadership, vol. 15, no. 2, pp. 153-168.

Jiménez-Jiménez, D., \& Sanz-Valle, R., (2011), Innovation, organizational learning, and performance, Journal of Business Research, vol. 64, no. 4, pp. 408-417.

Keskin, H., (2006), Market orientation, learning orientation, and innovation capabilities in SMEs, European Journal of Innovation Management, vol. 9, no. 4, pp. 396-417. 
Kohli, A. K., \& Jaworski, B. J., (1990), Market orientation: The construct, research propositions, and managerial implications, Journal of Marketing, vol. 54, pp. 1-18.

Kotter, J., \& Heskett, J., (1992), Corporate culture and performance, Free Press.

Kaasa, A., \& Vadi, M., (2008), How does the culture contribute to innovation? Evidence from European Countries, University of Tartu - Faculty of Economics and Business Administration working paper series 63, Faculty of Economics and Business Administration, University of Tartu.

Kanter, R. M., (1983), The change masters: Innovation for productivity in the American corporation, Simon and Schuster.

Laforet, S., \& Tann, J., (2006), Innovative characteristics of small manufacturing firms, Journal of Small Business and Enterprise Development, vol. 13, no. 3, pp. 363-380.

Lee, T. S., \& Tsai, H. J., (2005), The effects of business operation mode on market orientation, learning orientation and innovativeness, Industry Management Data System, vol. 105, no. 3, pp. 325-348.

Lee, C., \& Lee, C. G., (2007), SME innovation in the Malaysian manufacturing sector, Economics Bulletin, vol. 12, no. 30, pp. 1-12.

MacKenzie, S. B., Podsakoff, P. M., \& Jarvis, C. B., (2005), The problem of measurement model misspecification in behavioral and organizational research and some recommended solutions, Journal of Applied Psychology, vol. 90, no. 4, pp. 710-730.

Mamun, A. A., Fazal, S. A., Mohiuddin, M., \& Su, Z., (2019), Strategic Orientations, the mediating effect of absorptive capacity and innovation: A study among Malaysian manufacturing SMEs, International Journal of Innovation Management, vol. 23, no. 2, pp. 1-25.

Martins, E. C., \& Terblanche, F., (2003), Building organizational culture that stimulates creativity and innovation, European Journal of Innovation Management, vol. 6, no. 1, pp. 64-74.

Madhoushi, M., Sadati, A., Delavari, H., Mehdivand, M., \& Mihandost, R., (2011), Entrepreneurial orientation and innovation performance: The mediating role of knowledge management, Asian Journal of Business Management, vol. 3, no. 4, pp. 310-316.

Minh, T. T., \& Hjortsø, C. H., (2015), How institutions influence SME innovation and networking practices: The case of Vietnamese agribusiness, Journal of Small Business Management, vol. 53, no. 1, pp. 209-228.

Ministry of Science, Technology and Innovation, (2012), "Third outline perspective plan", Retrieved from http://nitc.mosti.gov.my

Mohd Fauzi, M. J., Ohe, T., Tih, S., Darawi, Z., Ahmad Azmi, M. A., Rozita, A. M. R., \& Ahmad Raflis, C. O., (2010), Entrepreneurship education and small and medium enterprises development, Centre For Entrepreneurship and Small and Medium Enterprises Development (CESMED), Universiti Kebangsaan Makaysia (UKM).

Massa, S., \& Testa, S., (2008), Innovation and SMEs: Misaligned perspectives and goals among entrepreneurs, academics, and policy makers, Technovation, vol. 28, no. 7, pp. 393-407.

Mavondo F., T., Chimhanzi, J., \& Stewart, J., (2005), Learning orientation and market orientation, European Journal of Marketing, vol. 39, no. 11/12, pp. 1235 -1263.

Narver, J. C., \& Slater, S. F., (1990), The effect of a market orientation on business profitability, Journal of Marketing, vol. 54, no. 4, pp. 20-35.

National Economic Advisory, (2010), "Economic transformation programme report", Retrieved from http://www.neac.gov.my/node/80

Nasution, H. N., Mavondo, F. T., Matanda, M. J., \& Ndubisi, N. O., (2011), Entrepreneurship: Its relationship with market orientation and learning orientation and as antecedents to innovation and customer value, Industrial Marketing Management, vol. 40, pp. 336-345. 
Ngah, R., \& Ibrahim, A. R., (2012), The relationship of intellectual capital, innovation and organizational performance: A preliminary study in Malaysian SMEs, International Journal of Management Innovation Systems, vol. 1, no. 1, pp. 1-13.

O'Cass, A., \& Ngo, L., (2007), Market orientation versus innovative culture: Two routes to superior brand performance, European Journal of Marketing, vol. 41, no. 7-8, pp. 868-887.

Oke, A., Burke, G., \& Myers, A., (2007), Innovation types and performance in growing UK SMEs, International Journal of Operations \& Production Management, vol. 27, no. 7, pp. 735-753.

Perez Lopez, S., Montes Peon, C. J., \& Vazquez, O., (2004), Managing knowledge: The link between culture and organizational learning, Journal of Knowledge Management, vol. 8, no. 6, pp. 93-104.

Pérez-Luño, A., Saparito, P., \& Gopalakrishnan, S., (2016), Small and medium-sized enterprise's entrepreneurial versus market orientation and the creation of tacit knowledge, Journal of Small Business Management, vol. 54, no. 1, pp. 262-278.

Peterson, R. T., (1988), An analysis of new product ideas in small business, Journal of Small Business Management, vol. 26, pp. 25-31.

Podsakoff, P. M., MacKenzie, S. B. B., Le, J-Y., \& Podsakoff, N. P., (2003), Common method biases in behavioral research: A critical review of the literature and recommended remedies, Journal of Applied Psychology, vol. 88, no. 5, pp. 879-903.

Podsakoff, P. M., \& Organ, D. W., (1986), Self-reports in organizational research: Problems and prospects, Journal of Management, vol. 12, no. 4, pp. 531-544.

Ringle, C. M., Wende, S., \& Becker, J. M., (2015), "SmartPLS 3", Retrieved from www.smartpls.com

Raduan, C. R., Jegak, U., Haslinda, A., \& Alimin, I. I., (2009), A conceptual framework of the relationship between organizational resources, capabilities, systems, competitive advantage and performance, Research Journal of Internatıonal Studıes, vol. 12, pp. 45-58.

Raju P. S., Lonial, S. C., \& Crum, M. D., (2011), Market orientation in the context of SMEs: A conceptual framework, Journal of Business Research, vol. 64, no. 12, pp. 13201326.

Shah Alam, S., \& Mohd Yasin, N., (2010), The antecedents of online brand trust: Malaysian evidence, Journal of Business Economics and Management, vol. 11, no. 2, pp. 210226.

Sharifirad, M. S., \& Atei, V., (2012), Organizational culture and innovation culture: Exploring the relationships between constructs, Leadership \& Organization Development Journal, vol. 33, no. 5, pp. $494-517$.

Sackmann, S. A., (1991), Cultural knowledge in the organization: Exploring collective mind, Newbury Park.

Sarooghi, H., Libaers, D., \& Burkemper, A., (2015), Examining the relationship between creativity and innovation: A meta-analysis of organizational, cultural, and environmental factors, Journal of Business Venturing, vol. 30, no. 5, pp. 714-731.

Schumpeter, J. A., (1934), The theory of economic development, Harvard University Press.

Scott, S. G., \& Bruce, R. A., (1994), Determinants of innovative behavior: A path model of individual innovation in the workplace, Academy of Management Journal, vol. 37, pp. 580-607.

Sorensen, J. B., (2002), The strength of corporate culture and the reliability of firm performance, Administrative Science Quarterly, vol. 47, pp. 70-91.

Subramanian, A., \& Nilakanta, S., (1996), Organizational innovativeness: Exploring the relationship between organizational determinants of innovation, types of innovation, and measures of organizational performance, International Journal of Management Science, vol. 24, no. 6, pp. 631-647.

Skerlavaj, M., Song, J. H., \& Lee, Y., (2010), Organizational learning culture, innovative culture and innovations in South Korean firms, Expert Systems with Applications, vol. 37, no. 9, pp. 6390-6403. 
SME Corp Malaysia (2019), "About SME masterplan (2012-2020)", Retreived from http://www.smecorp.gov.my/index.php/en/policies/2015-12-21-09-16-12/about-smemasterplan

Strategy Package for Higher Growth and Structural change, (2009), "Economic planning unit: MoF policy reseach institute, Japan", Retrieved from http://www.epu.gov.my

Streets, R., \& Boundary, C., (2004), Managing innovation, Australian Institute of Management.

Tushman, M. L., \& O’Reilly, C. A., (1997), Winning through innovation: A practical guide to leading organizational change and renewal, Harvard Business Press.

Ussahawanitchakit, P., (2008), Impacts of organizational learning on innovation orientation and firm efficiency: An empirical assessment of accounting firms in Thailand, International Journal of Business Resource, vol. 8, no. 4, pp. 1-12.

Wan Khairuzzaman, W. I., \& Abdmajid, R., (2007), Framework of the culture of innovation: A revisit, Jurnal Kemanusiaan, vol. 9, pp.38-49.

Wilson, P., \& Bates, S., (2003), The essential guide to managing small business growth, John Wiley \& Sons.

Zeng, S. X., Xie, X. M., \& Tam, C. M., (2010), Overcoming barriers to innovation in SMEs in China: A perspective based cooperation network, Innovation: Management, Policy \& Practice, vol. 12, no. 3, pp. 298-310.

Zhu, Y., Wittmann, X., \& Peng, M. P., (2012), Institution-based barriers to innovation in SMEs in China, Asia Pacific Journal of Management, vol. 29, no. 4, pp. 1131-1142. 